\title{
The Formation Mechanism and Characterization of Al-Si Master Alloys from Sodium Fluosilicate
}

\author{
Gamal Mohamed Attia MAHRAN 1, 2, Abdel-Nasser Mohamed OMRAN ${ }^{2}$, \\ El-Sayed Sedek ABU SEIF ${ }^{1}$
}

\author{
${ }^{1}$ King Abdulaziz University, Jeddah 21589, Saudi Arabia \\ ${ }^{2}$ Mining and Metallurgical Department, Faculty of Engineering, Al-Azhar University, Qena 83513, Egypt \\ crossref http://dx.doi.org/10.5755/j01.ms.26.2.21896
}

Received 20 October 2018; accepted 15 December 2018

\begin{abstract}
A modified Al-Si alloy containing up to $15 \mathrm{wt} . \% \mathrm{Si}$ has been obtained from the reaction of sodium fluosilicate $\left(\mathrm{Na}_{2} \mathrm{SiF}_{6}\right)$ with molten aluminum. This work attempted to estimate the mechanism of the reaction of $\mathrm{Na}_{2} \mathrm{SiF}_{6}$ with molten aluminum to produce Al-Si alloys. The effect of temperature, $\mathrm{Na}_{2} \mathrm{SiF}_{6} / \mathrm{Al}$ Wt ratio and reaction time on the formation of Al-Si alloy were investigated. The thermodynamic data, kinetic and rate of the reaction were studied. The results showed the possibility of the reaction between $\mathrm{Na}_{2} \mathrm{SiF}_{6}$ and molten aluminum thermodynamically, and that this reaction might be controlled chemically. The current study aims to optimize the factors that affecting the preparation of a modified $\mathrm{Al}-\mathrm{Si}$ alloy from a reduction of sodium fluosilicate using molten aluminium. Temperature $950{ }^{\circ} \mathrm{C}$, reaction time 20-25 min and $\mathrm{Na}_{2} \mathrm{SiF}_{6} / \mathrm{Al} \mathrm{Wt}$ ratio related to the applied Si percentage. The prepared alloys could be modified due to the presence of $\mathrm{Na}_{2} \mathrm{SiF}_{6}$ in the used material as a source of sodium in response to modifying the produced $\mathrm{Al}-\mathrm{Si}$ alloys. The microstructure by using LOM, SEM, and EDX proved that the needle-like silicon converts to fine fibrous. The volume fraction of primary $\mathrm{Si}$ reduces and the eutectic point moves to a higher silicon concentration. The modification improves the wear characteristics and increases the tensile and hardness.

Keywords: Al-Si alloys, sodium fluosilicate, microstructure, mechanical properties, wear.
\end{abstract}

\section{INTRODUCTION}

Aluminium-silicon alloys that contain $\mathrm{Si}$ as the main alloying element covers more than ninety percent of the total manufactured $\mathrm{Al}$ castings and have wide range of uses, particularly in the automotive, aerospace and engineering sectors [1]. The importance of Al-Si alloys among aluminum cast products owing to their high castability, low specific gravity, low shrinkage, good weldability and good resistance to wear and corrosion [2]. The silicon content in the aluminium-silicon alloys ranged from 4-25\%. Al-Si alloys are further classified as hypoeutectic (less than $12 \% \mathrm{Si}$ ), eutectic (ranged from $12-13 \% \mathrm{Si}$ ) and hypereutectic (varied from $14-25 \% \mathrm{Si}$ ) based on the silicon concentration in the alloy [3,4]. The mechanical properties of the aluminium-silicon alloys depend on the distribution, shape, and size of eutectic and primary silicon phases. Roundness, goodness, and homogeneity of silicon particles increase the strength of Al-Si alloys [5,6]. By study, the mechanical and tribological properties proved to be the most important properties in several engineering industries and automobile applications as the wear and friction of components in such industries are the major problems. Many researchers have studied the abrasive and sliding wear behavior of aluminium-silicon [7]. The aluminium-silicon alloys properties depend, strongly, on the casting process, composition and melt treatment that used in the alloy. However, the commercial applications of these alloys

\footnotetext{
* Corresponding author. Tel.: +201005405357.

E-mail address: mranasser@hotmail.com (A. M. Omran)
}

depend on controlling the structure of the silicon phase [8]. Silicon particles normally formed as needles enveloping dendritic matrix. The massive silicon phases cause the fracture or early crack initiation, when the components of the alloy are in tension, and they have a detrimental effect on machinability, extrudability, ductility, and strength of the alloy [9]. However, few hundreds ppm of strontium $(\mathrm{Sr})$ and sodium $(\mathrm{Na})$, as modifiers, can result in very fine, fibrous structure that leads to improvements in the mechanical properties [10-12].

Grain refiners and modifiers could be added to the molten aluminium-silicon alloys to get a combined modification and grain refinement effects. However, refining the primary silicon particles alone without modifying the eutectic silicon phase does not increase the mechanical properties [13]. Both $\mathrm{Na}$ and $\mathrm{Sr}$ are active modifiers for aluminium-silicon eutectic. It is challenging to control and keep the modification effect of $\mathrm{Na}$ because of fading and oxidation losses, especially at higher temperatures, and because longer holding times are necessary but $\mathrm{Sr}$ does not cause such problems [14, 15].

On the other hand, the phosphate ores contain fluorine in the form of calcium fluoride that used in producing phosphoric acid and super-phosphate fertilizers. The average fluorine content of these ores is about $2-4 \%$. The fluorine-containing gases evolves during the production process in the form of silicon tetrafluoride $\left(\mathrm{SiF}_{4}\right)$ and hydrogen fluoride (HF), what causes air pollution problems. These gases being scrubbed by water to produce dilute fluosilicic acid. The produced fluosilicic acid could be converted into sodium fluosilicate (S.F), in the form of white crystals, by treatment with sodium chloride solution 
[1]. The amount of produced S.F as a by-product in superphosphate fertilizing plants was used in a small scale, such as ceramic, enamels, glass, etc. It used, as well, in producing cryolite and $\mathrm{AlF}_{3}$ salts, and required as an electrolyte in the aluminium reduction cells, essentially for the dissolution of alumina [16, 17].

This work aims to study the parameters that affecting the reaction of $\mathrm{Na}_{2} \mathrm{SiF}_{6}$ with molten aluminium to produce Al-Si alloys, such as temperature and time, as well as, to estimate the rates of reaction at different temperatures. An attempt is made to investigate the mechanism of formation aluminium-silicon alloys through the reaction of $\mathrm{Na}_{2} \mathrm{SiF}_{6}$ with the molten aluminium.

\section{EXPERIMENTAL}

\subsection{Materials}

The used aluminium in this study is of $99.7 \%$ purity, produced by Aluminium company of Egypt, is subjected to Elemental analysis as shown in Table 1.

Table 1. Chemical analysis in (wt.\%) of aluminium before melting

\begin{tabular}{|c|c|c|c|c|c|c|}
\hline $\mathrm{Fe}$ & $\mathrm{Si}$ & $\mathrm{Cu}$ & $\mathrm{Mn}$ & $\mathrm{Mg}$ & $\mathrm{Ti}$ & $\mathrm{Na}$ \\
\hline $0.03-.09$ & 0.01 & 0.005 & 0.004 & 0.004 & 0.005 & 0.005 \\
\hline
\end{tabular}

The sodium fluosilicate $\left(\mathrm{Na}_{2} \mathrm{SiF}_{6}\right)$ is powdered. The chemical analysis of the used of $\mathrm{Na}_{2} \mathrm{SiF}_{6}$ is shown in Table 2.

Table 2. The chemical analysis of the used sodium fluosilicate in this study

\begin{tabular}{|c|c|c|c|c|c|c|}
\hline \multicolumn{7}{|c|}{ Element, \% } \\
\hline $\mathrm{F}$ & $\mathrm{Si}$ & $\mathrm{Na}$ & $\mathrm{Fe}$ & $\mathrm{S}$ & $\mathrm{Ti}$ & $\mathrm{Ca}$ \\
\hline 57.54 & 14.02 & 23.72 & 0.001 & 0.001 & 0.0001 & 0.3 \\
\hline
\end{tabular}

\subsection{Procedure}

The experiments were performed in a vertical tube furnace provided by mechanical stirrer having speed and temperature controllers. The aluminium ( $250 \mathrm{~g}$ ) were charged into a silicon carbide crucible inside the furnace. The aluminium melt and hold at the required temperature $800-1000{ }^{\circ} \mathrm{C}$. The compacted $\mathrm{Na}_{2} \mathrm{SiF}_{6}$ material, that previously prepared, was added in a suitable amount, and the crucible content was agitated using mechanical stirrer (400 rpm). After specific times (5, 10, 15, 20, 25 and 30 minutes), the crucible has been withdrawn from the furnace and the upper layer of the mixture, the slag, has been skimmed. Then the molten alloy poured into cast iron molds (30 $\mathrm{mm}$ diameter and $25 \mathrm{~mm}$ depth) and the produced alloys were chemically analyzed. Series of experiments were executed for different $\mathrm{Na}_{2} \mathrm{SiF}_{6} / \mathrm{Al}$ ratio $(R)$, reaction time $(t)$ and temperature $(T)$. The prepared specimens were tested; by light optical Microscopy (LOM) Olympus model BX51, electron microscopy (SEM FEI Inspect S50, Germany) attached to EDS, and XRD (model D5000) with $\mathrm{Ni}$-filtered $\mathrm{Cu}-\mathrm{K} \beta$ radiation $(\lambda=1.5408 \mathrm{~A})$ Siemens made in Germany. The hardness test carried out using Brinell hardness (load $5 \mathrm{Kgf}, 1 / 16$ inch ball diameter according to ASTM-E10 and average 3 hardness readings were taken. The specimens for the tensile test were prepared according to ASTM-E8 for the tensile test and the test executed by using tensile test machine. The wear rate of the produced alloys was measured using a pin-on-disk testing device at a constant load of $0.886 \mathrm{Kgf}$, at the same sliding speed of $250 \mathrm{rpm}(4.5 \mathrm{~m} / \mathrm{s})$, the disk made of gray cast iron and the pin is represent the specimens each of them $6 \mathrm{~mm}$ diameter and $40 \mathrm{~mm}$ length.

\section{RESULTS AND DISCUSION}

\subsection{Effect of temperature}

The influence of temperature on the composition of the produced Al-Si alloys by reacting S.F with molten aluminium was studied. Other conditions are kept constant; stirring $400 \mathrm{rpm}$, time is $20 \mathrm{~min}$. and S.F/Al ratio is 1 . It can be seen from the Fig. 1 that the silicon percentage in the produced alloys increases by increasing the temperature from 800 to $950{ }^{\circ} \mathrm{C}$ and there was no remarkable increasing from 950 to $1000{ }^{\circ} \mathrm{C}$ and little decreasing at a temperature more than $1000{ }^{\circ} \mathrm{C}$. The increasing from 800 to $950{ }^{\circ} \mathrm{C}$ can be due to increasing of fluidity, which leads to increasing the percentage of Si that dissolved in the bath. These results are in agreement with that obtained in the literature [18]. It is found that decreasing $\mathrm{Si}$ at more than $1000{ }^{\circ} \mathrm{C}$ is due to some losses of silicon content in the produced alloys might be due to oxidation. Because of the analysis of the skimmed slag which produced at $1100{ }^{\circ} \mathrm{C}$ containing $\mathrm{Al}$ and $\mathrm{Si} \%$ about $1 \%$ each more than the removed slag, which produced at $1000{ }^{\circ} \mathrm{C}$.

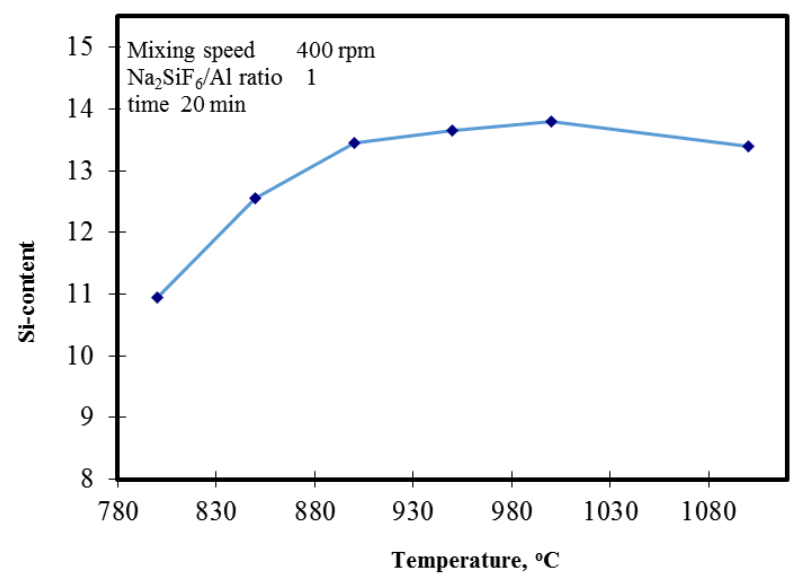

Fig. 1. Effect of temperature on the Si content in produced alloys

\subsection{Effect of $\mathrm{Na}_{2} \mathrm{SiF}_{6} / \mathrm{Al}$ ratio, $R$}

Fig. 2 shows the effect of $\mathrm{Na}_{2} \mathrm{SiF}_{6} / \mathrm{Al}$ ratio $(R)$ on $\mathrm{Si}$ contents in the produced alloys at mixing speed $400 \mathrm{rpm}$, temperature 900, and time $20 \mathrm{~min}$. From the Fig. 2, it can be noticed that the $\mathrm{Si} \%$ in the produced alloys increases linearly by increasing $\mathrm{Na}_{2} \mathrm{SiF}_{6} / \mathrm{Al}$ ratio in the range from 0.5 to 1.5 ratio, it reached up to $19 \% \mathrm{Si}$ at S.F/Al ratio $R$ equal to 1.5 . This is due to increasing the quantity of S.F in relation to the amount of molten aluminium. Imperatively, it was found, under similar conditions of the experiment, that the silicon content in the produced alloys does not reach more than $10 \%$ on carrying out the experiments without stirring $[18,19]$. In addition, the difference between the actual silicon content and theoretical silicon content increased as the $R$ increases. The efficiency of the 
reaction is relatively low if compared to that theoretically calculated to determine the silicon contents, as given in the following deduced equation from stiocmetry of the reaction:

$$
[\% \mathrm{Si}]_{\text {Theor }}=\frac{78 R}{(5.22-0.22 R)} \text {, }
$$

where $R$ is the $\mathrm{Na}_{2} \mathrm{SiF}_{6} / \mathrm{Al}$ wt. ratio.

The percentage of actual silicon in the produced alloy can be correlated by the empirical equation:

$\mathrm{Si} \%$ in the alloys $=12.6 R+0.25$,

where: $0.5<R<1.5$

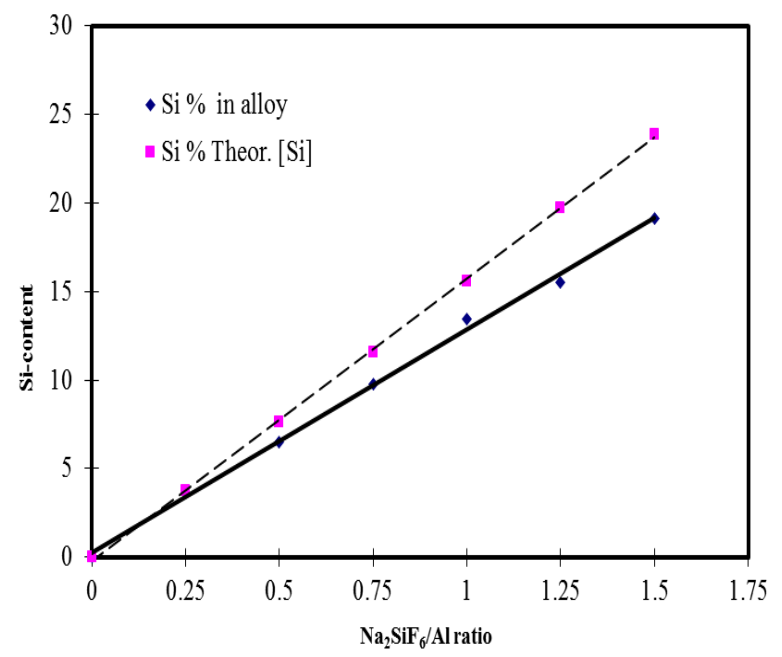

Fig. 2. Effect of $\mathrm{Na}_{2} \mathrm{SiF}_{6} / \mathrm{Al}$ ratio $(R)$ on $\mathrm{Si}$ contents in the produced alloys

\subsection{Effect of reaction time}

Fig. 3 shows the relation between the Si percentage in the produced aluminium-silicon alloys and the reaction time at different temperatures $800,850,900,950$, and 1000. The results demonstrated that the percentage of $\mathrm{Si}$ in the produced alloys increases by increasing the reaction time in the range of 5 to $25 \mathrm{~min}$, a further increase in the reaction time leads to a little decrease in $\mathrm{Si}$ percentage. Increasing the $\mathrm{Si} \%$ contents in the produced alloys by increasing reaction time in the range of 5 to $25 \mathrm{~min}$ is a normal result, but it needs sufficient time to complete the reaction. The little decreases of $\mathrm{Si}$ for larger reaction time might be due to the increasing of products and decreasing of reactants leads to decrease the reaction rate and drive the reaction toward the equilibrium at all temperatures.

Also from Fig. 3, the silicon percentage of the produced aluminium-silicon alloys at any reaction time increased as the temperature increases at 800, 850, 900, 950 and $1000{ }^{\circ} \mathrm{C}$. The fitting curves at these temperatures represent 5 lines in different slopes, the slop of each line represents the reaction rate $K$. The slopes of these lines increase by increasing the temperature. The logarithm of reaction rates $\ln K$ was plotted versus $1 / T$ according to Arrhenius equation as shown in Fig. 4. From this figure, it can be shown that the experimental results give a good fitting to Arrhenius equation. The slope of the straight line was calculated to be -3257.3 , from Arrhenius equation: $\ln K=\ln K_{o}-\frac{Q}{R}\left(\frac{1}{T}\right)$,

where $K$ is the reaction rate; $T$ is the temperature in Kelven degree; $R$ is the gas constant $\left(8.31 \mathrm{~J} \mathrm{~K}^{-1} \mathrm{~mol}^{-1}\right) ; Q$ is the activation energy

Hence $-\frac{Q}{R}=-3257.3$ and

$Q=27068 \mathrm{~J}=27 \mathrm{~kJ}$

From these results, it can be concluded that the reaction between molten aluminum and $\mathrm{Na}_{2} \mathrm{SiF}_{6}$ is a controlled chemical reaction [20].

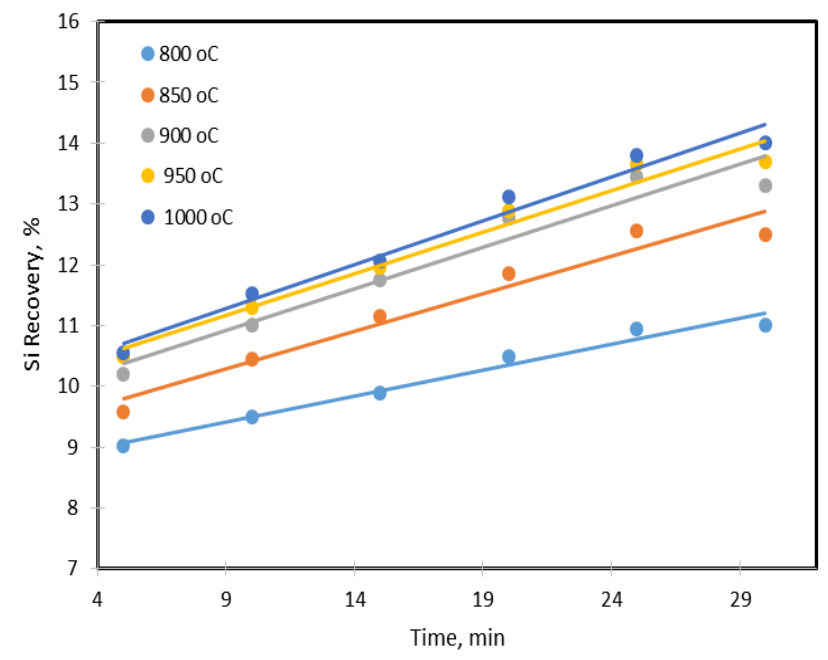

Fig. 3. The relation between the $\mathrm{Si}$ percentage in the produced aluminium-silicon alloys and the reaction time

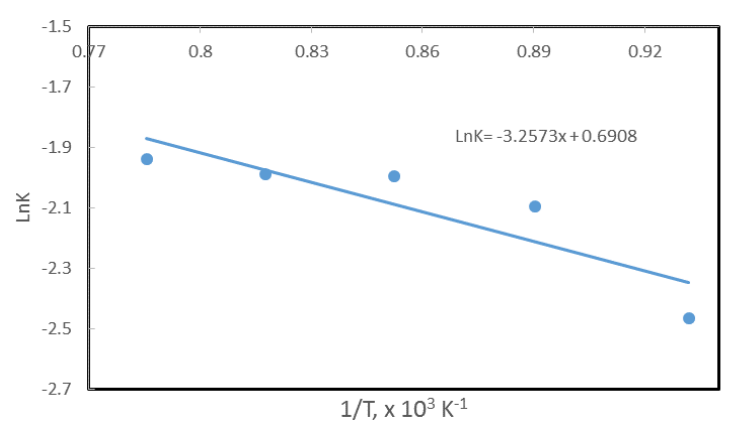

Fig. 4. Arrhenius plot between $\ln K$ and $1 / T$

From the above results, the reaction between sodium fluosilicate with molten aluminium is taken place as follows:

- In molten aluminium, sodium fluosilicate decomposes to silicon tetra-fluoride and sodium fluoride

$\mathrm{Na}_{2} \mathrm{SiF}_{6} \rightarrow 2 \mathrm{NaF}+\mathrm{SiF}_{4}$ (gas).

- From thermodynamic data, the Gib's free energy for the decomposition reaction of $\mathrm{Na}_{2} \mathrm{SiF}_{6}$ is $\Delta G=35080-42.51 T \mathrm{Cal} / \mathrm{mol}$

- The decomposition temperature can be obtained when $\Delta G=0$, then $T$ decomp $=825.22 K=552.22{ }^{\circ} \mathrm{C}$ 
This temperature was close to the temperature of endothermic peak that occurs at 568 as shown in Fig. 5. It represents the DTA for $\mathrm{Al}+\mathrm{Na}_{2} \mathrm{SiF}_{6}$ mixtures. From this figure, it could be seen that an endothermic peak at $563.26{ }^{\circ} \mathrm{C}$ represents the decomposition of $\mathrm{Na}_{2} \mathrm{SiF}_{6}$ to obtain sodium fluoride $\mathrm{NaF}$ and silicon tetrafluoride $\mathrm{SiF}_{4}$ that being adsorbed on the surface of aluminum powder according to Eq. 4. While the endothermic peak at $659.96{ }^{\circ} \mathrm{C}$ is the latent heat of fusion for aluminum, (melting point of $\mathrm{Al}$ at $660{ }^{\circ} \mathrm{C}$ ). The other exothermic peak, about $841.42{ }^{\circ} \mathrm{C}$ Fig. 5 might be for $\mathrm{Al}$ and $\mathrm{Na}_{2} \mathrm{SiF}_{6}$ to obtain Al-Si alloy with $\mathrm{AlF}_{3}$ according to Eq. 5:

$6 \mathrm{NaF}+3 \mathrm{SiF}_{4}+4 \mathrm{Al} \rightarrow 2 \mathrm{Na}_{3} \mathrm{AlF}_{6}+2 \mathrm{AlF}_{3}+3 \mathrm{Si}$ (alloy).

$G=-149 \mathrm{Kcal}$ at 841.42 and the negative sign make the reaction possible or spontaneous.

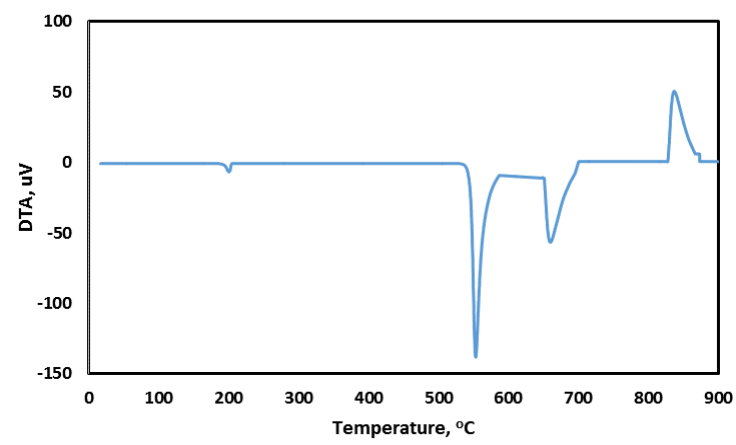

Fig. 5. DTA for $\mathrm{Al}+\mathrm{Na}_{2} \mathrm{SiF}_{6}$ mixtures

The $\mathrm{SiF}_{4}$ makes small bubbles surrounded by $\mathrm{Si}$ enriched layer, as shown in Fig. 6, which in turn transfers into molten aluminum by diffusion producing Al-Si alloy. While increasing the bath height may lead to increasing the contact time between molten aluminum and the bubbles bearing $\mathrm{Si}$.

From the above results, it can be established that the rate of dissolution of $\mathrm{Si}$ in molten aluminum is chiefly governed either by the rate of $\mathrm{Si}$ formation or by the rate of diffusion of $\mathrm{Si}$ into molten aluminum. The obtained experimental data from Fig. 5 proved that the rate of $\mathrm{Si}$ formation proceeds according to Eq. 5 .

On the other hand, as shown in Fig. 5, the diffusion of [Si] on the $\mathrm{SiF}_{4}$ bubble from the boundary layer into molten Al plays a major role in forming $\mathrm{Al}-\mathrm{Si}$ and it could be the rate-controlling step.

The changing rate in concentration of $\mathrm{B}$ in the boundary layer $[\mathrm{B}] \mathrm{o}$ and boron concentration within the molten aluminium $[\mathrm{B}]_{\mathrm{x}}$ can be explained according to the following relation:

$$
\frac{d[S i]_{\mathrm{X}}}{d t}=k\left[(S i)_{o}-(S i)_{x}\right],
$$

where $K$ is the factor of proportionality, which in turn is a function of the diffusion coefficient of $\mathrm{Si}$ in $\mathrm{Al}$ [20]. I.e. the reaction velocity is proportional to the instantaneous concentration. Integrating Eq. 6 with respect to time $t$ :

$k t=\ln \frac{[\mathrm{Si}]_{o}}{\left\{[\mathrm{Si}]_{o}-[\mathrm{Si}]_{x}\right\}}$, where $[\mathrm{Si}]_{\mathrm{o}}$ is the theoretical concentration of $\mathrm{Si}$ in the bath, i.e. all $\mathrm{Si}$ in $\mathrm{SiF}_{4}$ could be converted into $\mathrm{Si}$ in the alloy; $[\mathrm{Si}]_{\mathrm{x}}$ is the concentration of $\mathrm{Si}$ in the produced alloy after a period of time $t$.

As expected, the mixing process may affect the mass transfer of Si to molten Al. In the form of Eq. 8, using the measured concentration values at different times is useful for determining the $K$ value of reaction. From the above results, it can be concluded that the diffusion of $\mathrm{Si}$ from the boundary layer of the $\mathrm{SiF}_{4}$ bubble to the bulk of the molten aluminum is a rate-controlling step. These results indicate that increasing the mixing speed and bath height increase the rate of Si recovery.

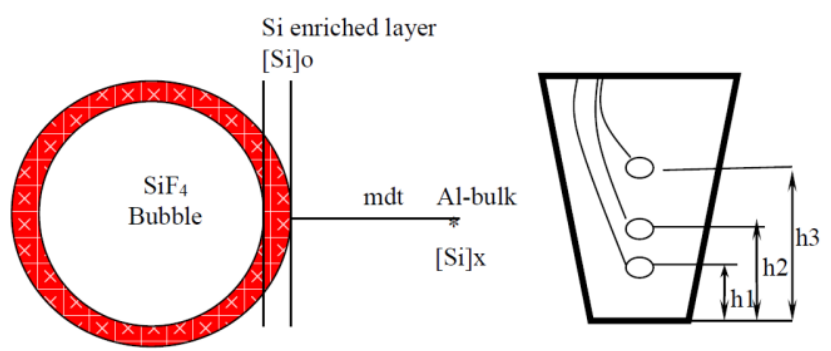

Fig. 6. Sketch for boundary layer formation

\subsection{Characterization of the produced alloys}

X-ray diffraction analysis (XRD) was done using Siemens D5000 diffractometer, German model using $\mathrm{Cu}$ radiation set at step size $0.02^{\circ}$ and step time 0.1 . The XRD pattern for $\mathrm{Al}-\mathrm{Si}$ alloy containing $7 \mathrm{Si}$. Fig. 7 illustrates that there are two phases founded $\alpha \mathrm{Al}$ and aluminium silicon alloy A13.21Si0.47. The aluminium silicon alloy $\mathrm{Al3} .21 \mathrm{Si0.47}$ that contains about 87.3 at $\% \mathrm{Al}$ and 12.7 at $\% \mathrm{Si}$ represents the eutectic composition.

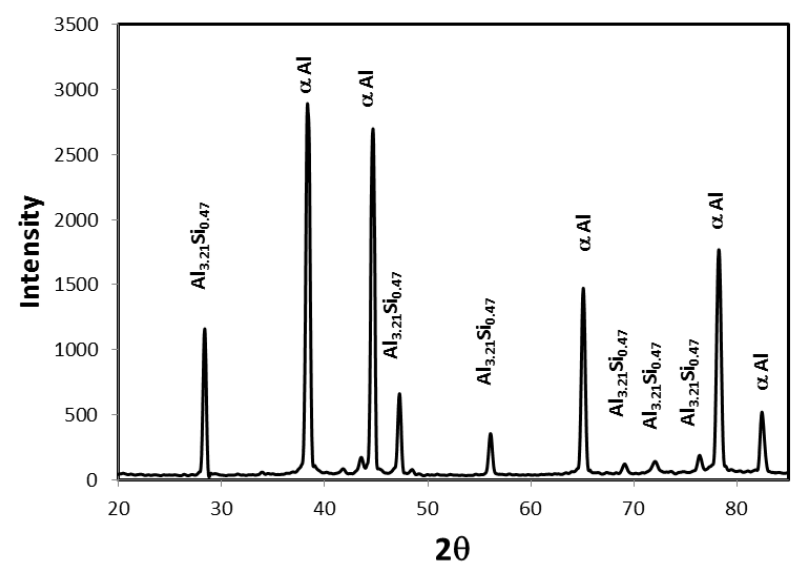

Fig. 7. XRD pattern for the produced Al-7Si alloy produced by $\mathrm{Na}_{2} \mathrm{SiF}_{6}$

Fig. 8 shows light optical microscopy (LOM) micrographs of the produced $\mathrm{Al}-\mathrm{Si}$ alloys at $\mathrm{Si}$ contents $7 \% \mathrm{Si}$ modified by $\mathrm{Na}_{2} \mathrm{SiF}_{6}$. From this figure, it can be seen that a kidney shape $\alpha \mathrm{Al}$ (white area) surrounded by uniformed fine fibrous eutectic Si (dark grey).

Fig. 9 shows LOM micrographs of the produced $\mathrm{Al}-\mathrm{Si}$ alloys at $\mathrm{Si}$ content $15 \% \mathrm{Si}$ produced and modified by $\mathrm{Na}_{2} \mathrm{SiF}_{6}$. It can be observed that the matrix contains fibrous eutectic Si (gray color) and primary Si (black color), but the primary silicon reduces in its amount and becomes of 
smaller size than the primary $\mathrm{Si}$ in usual (without modification) [20].

Adding sodium salts in form of $\mathrm{Na}_{2} \mathrm{SiF}_{6}$ to Al-Si alloys leads to modification of the microstructure and exchanges the point of the eutectic to a higher Si concentration.

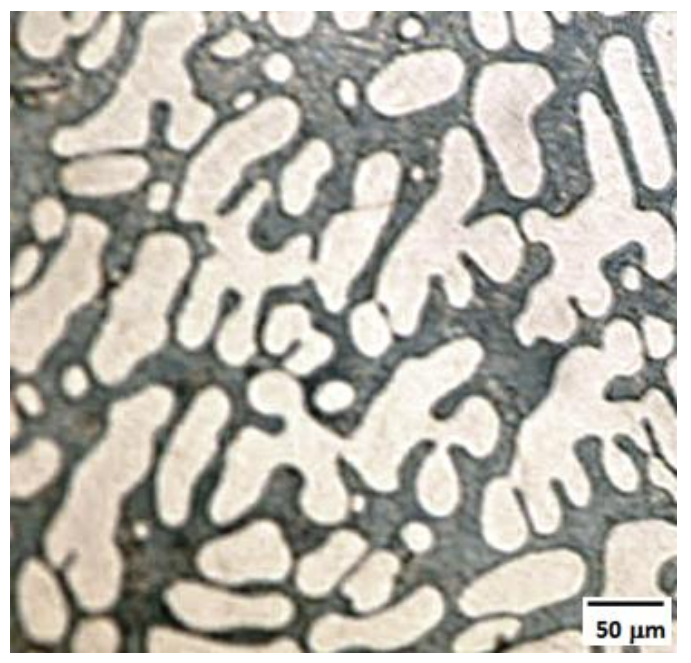

Fig. 8. LOM micrographs of the produced $\mathrm{Al}-\mathrm{Si}$ alloys at $\mathrm{Si}$ contents $7 \% \mathrm{Si}$ produced by $\mathrm{Na}_{2} \mathrm{SiF}_{6}$

The aim of modifying the eutectic Si is to produce a fine fibrous form rather than the needle shape (Fig. 9). The eutectic point has shifted far enough to more than $13 \% \mathrm{Si}$, at this composition, hypoeutectic instead of hypereutectic [21].

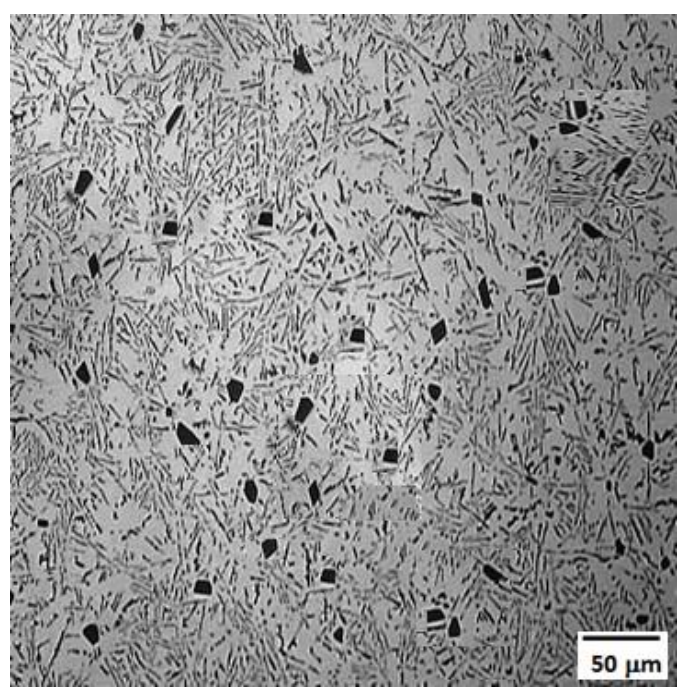

Fig. 9. LOM micrographs of the produced aluminium-silicon at Si contents $15 \%$ Si produced by $\% \mathrm{Na}_{2} \mathrm{SiF}_{6}$

Fig. 10 shows SEM and EDS mapping images of the produced aluminium-silicon alloys containing $7 \% \mathrm{Si}$ modified by sodium salts. The Fig. 10 a shows SEM image; the distribution of eutectic Si (lighted particle) and $\alpha \mathrm{Al}$ (grey) in the matrix. It can notice that the finer fibrous in form of eutectic Si (lighted particle) around the grey area ( $\alpha \mathrm{Al}$ ). By comparing Fig. 10 b, c to Fig. 10 a, it can be found that the fine light green color is eutectic Si around a dark color is $\alpha \mathrm{Al}$ but the red color particles is $\alpha$ Al surrounded by eutectic silicon particles (dark color) Fig. 10 c.
The ultimate tensile strength values (UTS) of the aluminium-silicon alloys at different percentages of $\mathrm{Si}$ (5, $7,9,11,13$ and $15 \%$ ) modified by $\mathrm{Na}_{2} \mathrm{SiF}_{6}$ salts were measured as shown in Fig. 11.

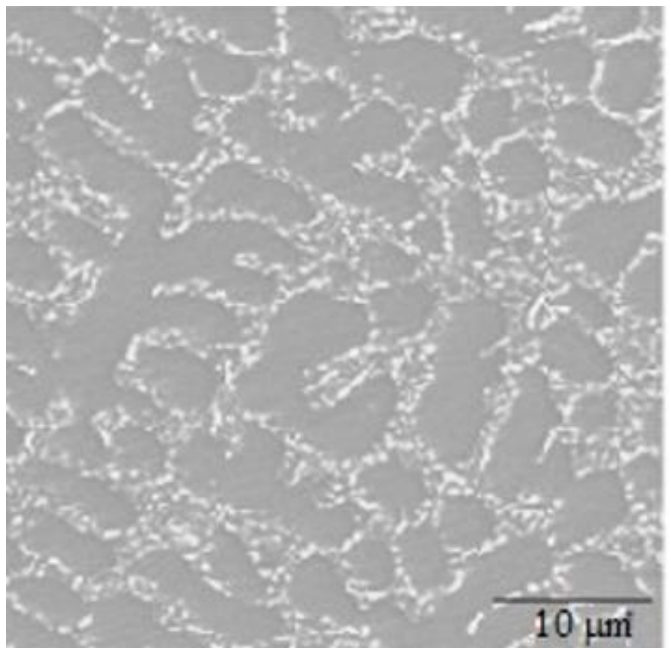

a

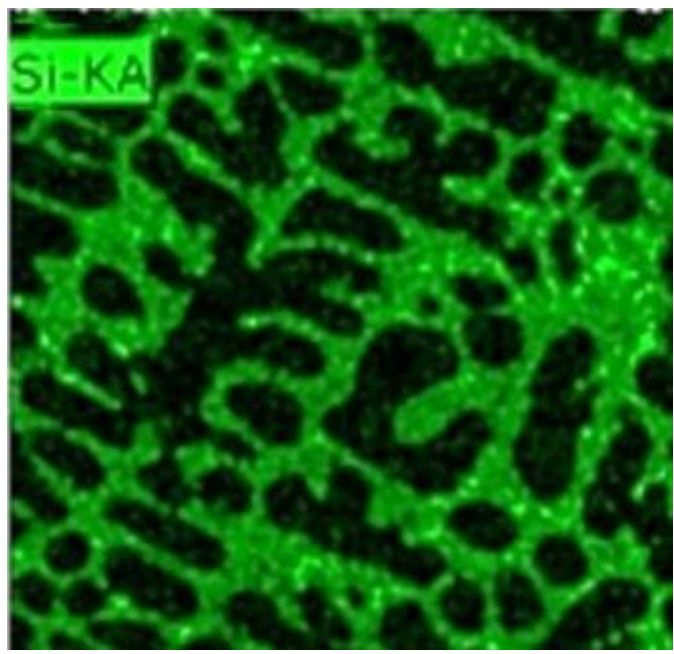

b

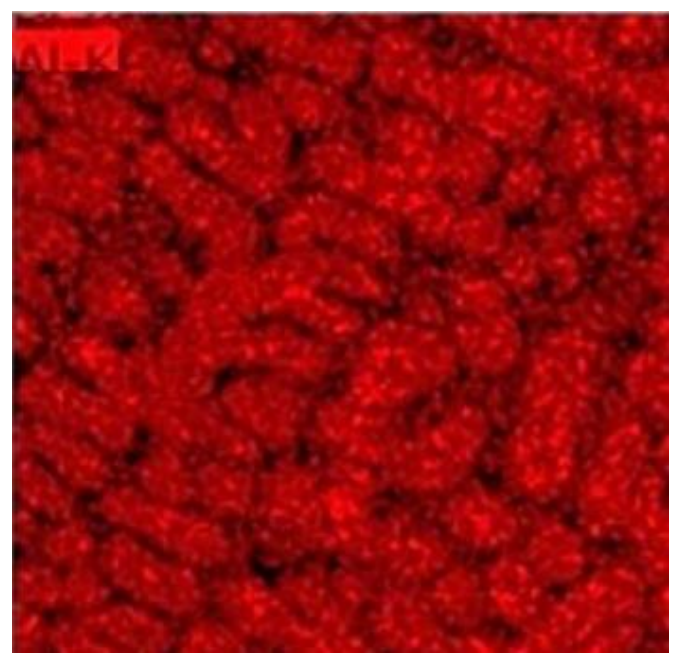

c

Fig. 10. SEM and EDS mapping images of the produced aluminium-silicon alloys containing $7 \%$ Si modified by $\mathrm{Na}_{2} \mathrm{SiF}_{6}$ salts: $\mathrm{a}-\mathrm{SEM}$ micrographs of the produced Al$\mathrm{Si}$ alloys at $\mathrm{Si}$ contents $7 \% \mathrm{Si}$ produced by $\mathrm{Na}_{2} \mathrm{SiF}_{6}$; $\mathrm{b}$-EDS Mapping for Si particles; c-EDS Mapping for $\mathrm{Al}$ particles 
It shows the effect of modification by sodium, (using $\mathrm{Na}_{2} \mathrm{SiF}_{6}$ ) on the UTS values of the modified Al-Si alloys. It can be observed that UTS values increase linearly by increasing the silicon contents. In addition, the hardness of the aluminium-silicon alloys at different percentages of Si $(5,7,9,11,13$ and $15 \%)$ modified by $\mathrm{Na}_{2} \mathrm{SiF}_{6}$ salts increases linearly as the silicon contents increase.

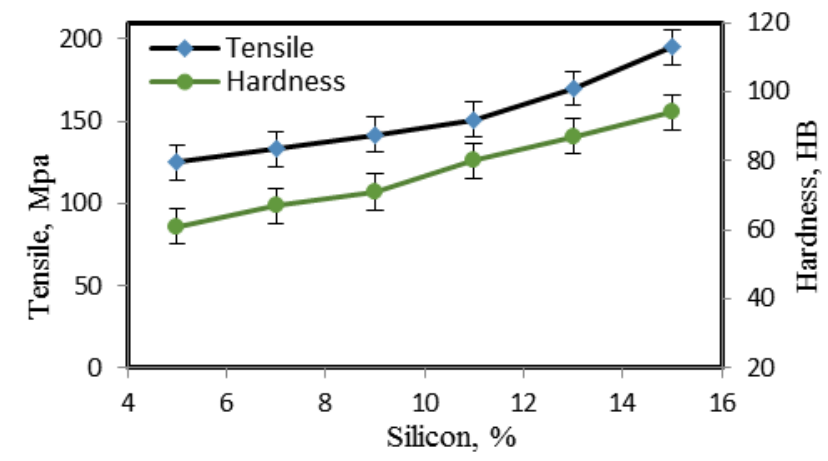

Fig. 11. Effect of Si \% on the hardness and tensile strength of aluminium-silicon alloys produced by $\mathrm{Na}_{2} \mathrm{SiF}_{6}$

The wear rate of the produced specimens of $\mathrm{Al}-\mathrm{Si}$ alloys that was obtained by using $\mathrm{Na}_{2} \mathrm{SiF}_{6}$, was measured at different Si contents $(5,7,9,11,13$ and $15 \%)$. The wear weight loss after wear test using a pin on disk apparatus under load $0.866 \mathrm{kgf}$, sliding speed of $4.5 \mathrm{~m} / \mathrm{s}(250 \mathrm{rpm})$ at time 7 hours, the results are indicated in Fig. 12. The wear weight loss of the produced aluminium-silicon with sodium modification reduces by increasing the $\mathrm{Si} \%$ in the produced Al-Si alloys. The decrease of wear weight loss by increasing the percentage of silicon in the produced aluminium-silicon might be due to the existence of strengthening silicon particles that observed in the alloy $[21,22]$. The wear rate as a function of $\mathrm{Si}$ contents could be correlated according to Eq. 8 .

wear rate, $\mathrm{g} / \mathrm{hr}=-0.039 \mathrm{Si} \%+0.606$,

where wear rate is the rate of wear loss with time at different $\mathrm{Si}$ contents and $\mathrm{Si} \%$ is the needed content of silicon.

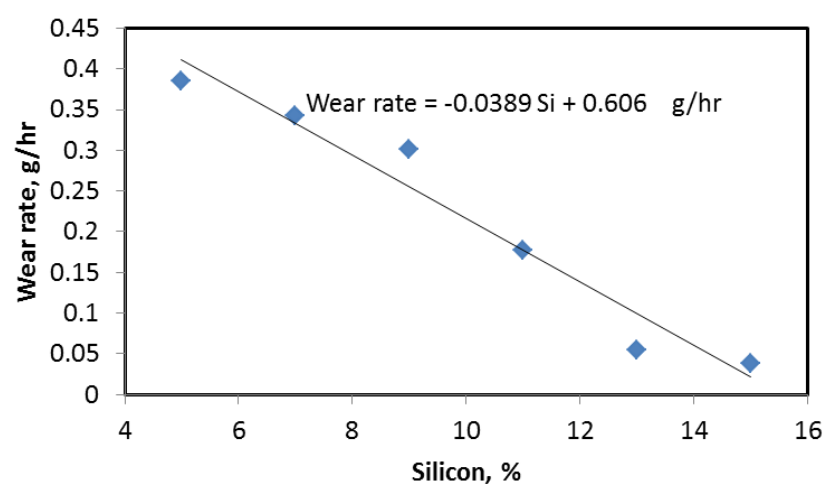

Fig. 12. Effect of $\mathrm{Si} \%$ on the wear rate of aluminium-silicon alloys produced by $\mathrm{Na}_{2} \mathrm{SiF}_{6}$

\section{CONCLUSIONS}

A study was achieved to optimize the factors that affecting the preparation of a modified Al-Si alloy from the reduction of sodium fluosilicate using molten aluminium. The main conclusions are as follows:

1. The optimum conditions for producing the $\mathrm{Al}-\mathrm{Si}$ alloys are; temperature $950{ }^{\circ} \mathrm{C}$, reaction time $20-$ $25 \mathrm{~min}$ and $\mathrm{Na}_{2} \mathrm{SiF}_{6} / \mathrm{Al}$ wt ratio depend on the $\mathrm{Si}$ percentage needed.

2. The prepared alloys are modified due to the presence of $\mathrm{Na}$ in the used material. The microstructures using LOM, SEM, and EDX indicate that the silicon shape of the hypoeutectic converted from needle to fine fibrous $\mathrm{Si}$. However, at hypereutectic the primary silicon reduces in the volume fraction and size what leads to improving the morphology of all matrix.

3. The modification improves the wear and mechanical properties.

\section{Acknowledgments}

This project was funded by the Deanship of Scientific Research (DSR) at King Abdulaziz University, Jeddah, under grant No. (G:483-306-1439). The authors, therefore, acknowledge with thanks DSR for technical and financial support.

\section{REFERENCES}

1. Stadler, F., Antrekowitsch, H., Fragner, W., Kaufmann, H., Uggowitzer, P.J. Effect of Main Alloying Elements on Strength of Al-Si Foundry Alloys at Elevated Temperatures International Journal of Cast Metals Research 25 (4) 2012: pp. 215-224.

https://doi.org/10.1179/1743133612Y.0000000004

2. Vijeesh, V., Prabhu, K.N. Review of Microstructure Evolution in Hypereutectic Al-Si Alloys and Its Effect on Wear Properties Transactions of the Indian Institute of Metals 67 (1) 2014: pp. 1-18. https://doi.org/10.1007/s12666-013-0327-x

3. Sjölander, E., Seifeddine, S. The Heat Treatment of Al-Si$\mathrm{Cu}-\mathrm{Mg}$ Casting Alloys Journal of Materials Processing Technology 210 (10) 2010: pp. 1249-1259. https://doi.org/10.1016/j.jmatprotec.2010.03.020

4. Asghar, Z., Requena, G., Kubel, F. The Role of Ni and Fe Aluminides on the Elevated Temperature Strength of an AlSi12 Alloy Materials Science and Engineering: A 527 (21-22) 2010: pp. 5691-5698. https://doi.org/10.1016/j.msea.2010.05.033

5. Sjölander, E., Seifeddine, S. The Heat Treatment of Al-Si$\mathrm{Cu}-\mathrm{Mg}$ Casting Alloys Journal of Materials Processing Technology 210 (10) 2010: pp. 1249-1259. https://doi.org/10.1016/j.jmatprotec.2010.03.020

6. Stadler, F., Antrekowitsch, H., Fragner, W., Kaufmann, H., Uggowitzer, P.J. The Influence of Solution Treatment on the High-Temperature Strength of $\mathrm{Al}-\mathrm{Si}$ Foundry Alloys with Ni. In: Suarez C.E. (eds) Light Metals 2012. Springer, Cham https://doi.org/10.1007/978-3-319-48179-1_73

7. Stadler, F., Antrekowitsch, H., Fragner, W., Kaufmann, H., Uggowitzer, P.J. The Effect of Ni on the High-Temperature Strength of Al-Si Cast Alloys Materials Science Forum 690 2011: pp. 274-277. https://doi.org/10.4028/www.scientific.net/MSF.690.274

8. Elmadagli, M., Perry, T., Alpas, A.T. A Parametric Study of the relationship between microstructure and wear Resistance of Al-Si Alloys Wear $262(1-2)$ 2007: pp. $79-92$. 
https://doi.org/10.1016/j.wear.2006.03.043

9. Kim, M. Electron Back Scattering Diffraction (EBSD) Analysis of Hypereutectic Al-Si Alloys Modified by $\mathrm{Sr}$ and Sc Metals and Materials International $13(2)$ 2007: pp. $103-107$. https://doi.org/10.1007/BF03027559

10. Mahato, A., Xia, S., Perry, T., Sachdev, A. Biswas, S.K. Role of Silicon in Resisting Subsurface Plastic Deformation in Tribology of Aluminium-Silicon Alloys Tribology International $43(1-2)$ 2010: pp. 381-387. https://doi.org/10.1016/j.triboint.2009.06.020

11. Nayak, S., Karthik, A. Synthesis of Al-Si Alloys and Study of Their Mechanical Properties A Thesis Submitted for the award of B.Sc., National Institute of Technology, Rourkela, India, 2011. http://ethesis.nitrkl.ac.in/2136/1/107MM004-107MM036.pdf

12. Zhongwei, C., Zhang, R. Effect of Strontium on Primary Dendrite and Eutectic Temperature of A357 Aluminium Alloy China Foundry Journal 7 (2) 2010: pp. 149-152.

13. Sigworth, G. The Modification of Al-Si Casting Alloys: Important Practical and Theoretical Aspects International Journal of Metal casting 2(2) 2008: pp. $19-40$. https://doi.org/10.1007/BF03355425

14. Jiang, Q., Xu, C., Wang, H, Wang, J. Yang, Y. Estimation of the Shifting Distance of the Eutectic Point in Hypereutectic Al-Si Alloys by the Lever Rule Scripta Materialia 56 (5) 2007: pp. 329-332. https://doi.org/10.1016/j.scriptamat.2006.11.023

15. Nowak, M., Hari Babu, N. Novel Grain Refiner for Hypo and Hypereutectic Al-Si Alloys Materials Science Forum 690 2011: pp. 49-52.

https://doi.org/10.4028/www.scientific.net/MSF.690.49
16. Kanble, A. Grain Refiners and Modifiers for the Aluminum foundry, 36 June 2014, Metal world. http://metalworld.co.in/newsletter/2014/Jun14/Technology0614.pdf

17. Mallapur, D., Raudupa, K., Kori, S. Influence of Grain refiner and modifier on the microstructure and mechanical Properties A356 Alloy International Journal of Engineering Science and Technology 2 (9) 2010: pp. $4487-4493$. http://www.ijest.info/docs/IJEST10-02-09-33.pdf

18. Ebrahim, E., Aly, I., Nofal, A. Ahmed, F., Omran, A. Preparation of Al-Si Alloys Using Sodium - Fluosilicate and Molten Aluminium Metall 52 (12) 1998: pp. 712-715.

19. Aly, I., Ebrahiem, E., Noval, A., Omran, A. Dissolution Kinetics of Silicon-Containing Sodium Fluosilicate in Stirred Bath of Molten Aluminium Annual meeting; 131st, The Minerals, Metals \& Materials Society; Light metals 2002, proceedings of the technical sessions presented by the TMS Aluminum Committee at the 131st TMA Annual Meeting; 2002; Seattle, WA.

20. Gong, C., Tu, H., Wu, C., Wang, J., Su, X. Study on Microstructure and Mechanical Properties of Hypereutectic Al-18Si Alloy Modified with Al-3B Materials $11(3)$ 2018: pp. $456-465$. https://doi.org/10.3390/ma11030456

21. Fredriksson, H., Akerlind, U. Materials Processing During Casting, John Wiley \& Sons Ltd, Chichester, 2006. https://onlinelibrary.wiley.com/doi/book/10.1002/9780470017920

22. Wang, S., Ya Liu, Y., Peng, H., Lu, X., Wang, J., Su, X. Microstructure and Mechanical Properties of Al-12.6Si Eutectic Alloy Modified with Al-5Ti Master Alloy Advanced Engineering Materials 19 (12) 2017: pp. 1-5. https://doi.org/10.1002/adem.201700495 